\title{
Pengaruh Penambahan Kelopak Bunga Rosella Pada Pembuatan Fruit Leather Dari Buah Mangga
}

\author{
Effect Of Additions Flowers Of Rosella Interest In Making Fruit Leather \\ From Mango Fruit \\ Muhammad Nuh \\ Program Studi Teknologi Hasil Pertanian \\ Fakultas Pertanian Universitas Islam Sumatera Utara \\ mhd_nuh67@yahoo.com
}

\begin{abstract}
ABSTRAK
Buah-buahan tidak selalu dikonsumsi dalam bentuk segar. Tetapi sebagian besar diolah menjadi berbagai bentuk dan jenis makanan. Pengolahan ini bertujuan selain untuk memperpanjang masa simpan, juga untuk meningkatkan aneka ragam produk. Buah-buahan umumnya diolah menjadi olahan seperti jam, jelly, selai, puree, sari buah, buah kaleng, manisan kering atau basah. Salah satu jenis produk buah-buahan yang kering selain manisan buah-buahan adalah Fruit leather. Fruit leather adalah jenis makanan dari daging buah yang telah dihancurkan dan dikeringkan. Pengeringan bisa dilakukan dengan penjemuran atau bisa juga dengan pemanasan yang memiliki suhu panas $50-60^{\circ} \mathrm{C}$. Fruit leather memiliki daya simpan sampai 12 bulan, bila disimpan pada kondisi penyimpanan yang sesuai. Di Indonesia, Fruit leather masih belum diproduksi secara komersial. Rossela mengandung beberapa zat yang sangat penting bagi kesehatan. diantaranya grossy peptin, antochanin, gluside hibiscin, dan flavonoid yang bermanfaat mencegah kanker, mengendalikan tekanan darah, melancarkan peredaran darah dan sebagainya. Kandungan seratnya pun cukup tinggi yang berperan dalam melancarkan sistem pembuangan dan menurunkan kadar kolesterol dalam darah (Erianto, 2009). Berdasarkan latar belakang tersebut maka penelitian ini dilakukan untuk mengkombinasikan buah mangga yang diketahui memiliki kandungan gizi yang tinggi dengan bunga rosella yang memiliki beberapa zat yang sangat penting bagi kesehatan. Pelaksanaan Penelitian menggunakan Rancangan Acak Lengkap (RAL) Faktorial, dengan dua faktor utama yaitu; Faktor I: Varietas buah mangga (M) yang terdiri dari 3 taraf; M1: Mangga udang, M2: Mangga harum manis, M3: Kueni. Faktor II: Penambahan rosella (\%) dari daging buah mangga, yang terdiri dari 4 taraf; R1: $40 \%$, R2: 60 \%, R3: 80\%, R4: 100\%. Penelitian dilaksanakan dengan 3 ulangan. Penelitian dilaksanakan pada bulan April hingga Mei 2017 di laboratoriu Teknologi Hasil Pertanian Fakultas Pertanian UISU Medan. Hasil Penelitian menunjukkan bahwa Kombinasi perlakuan terbaik diperoleh pada mangga Kueni dengan penambahan daging kolopak bunga rosella sebanyak 40\% (M3R1). Aroma dan rasa Kueni yang kuat menghasilkan fruit leather dengan nilai organoleptik rasa aroma warna tertinggi. Sebaliknya semakin tinggi persentase penambahan rosella mengakibatkan penilaian organoleptik rasa, warna dan aroma menurun.
\end{abstract}

Kata Kunci: Mangga, kueni, Rosella, Fruit Leather

\begin{abstract}
Fruits are not always consumed in fresh form. But most are processed into various forms and types of food. This treatment aims in addition to extending the shelf life, as well as to increase the variety of products. Fruits are generally processed into preparations such as jam, jelly, jam, puree, fruit juice, canned fruit, candied dry or wet. One type of dried fruit products other than candied fruits is Fruit leather. Fruit leather is a type of food of fruit flesh that has been destroyed and dried. Drying can
\end{abstract}


be done with drying or it could be with a warming that has a hot temperature of 50-60oC. Fruit leather has a shelf life of up to 12 months, when stored at appropriate storage conditions. In Indonesia, Fruit leather is still not commercially produced. Rossela contains some substances that are very important for health. Including grossy peptin, antochanin, gluside hibiscin, and flavonoids that are useful to prevent cancer, control blood pressure, blood circulation and so forth. The fiber content is high enough that plays a role in launching the exhaust system and lower cholesterol levels in the blood (Erianto, 2009). Based on this background then this study was conducted to combine the mango fruit is known to have high nutritional content with rosella flowers that have some substances that are very important for health. Implementation of Research using Factorial Random Design (RAL), with two main factors that is: Factor I: Varieties of mango fruit (M) consisting of 3 levels: M1: Mango shrimp, M2: sweet sweet Mango, M3: Kueni. Factor II: Addition of rosella (\%) of mango flesh, consisting of 4 levels: R1: 40\%, R2: 60\%, R3: 80\%, R4: 100\%. The study was conducted with 3 replications. The research was conducted from April to May 2017 at the laboratory of Agricultural Product Technology Faculty of Agriculture UISU Medan. The results showed that the best treatment combination was obtained in Kueni mango with 40\% rosella flower meat (M3R1). The strong aroma and taste of Kueni produce the fruit leather with the highest organoleptic value of the color scent. Conversely, the higher percentage of rosella addition resulted in organoleptic assessment of flavor, color and flavor decreased.

Keywords: Fruit leather, Mango, Queni, Rosella

\section{A. PENDAHULUAN}

Buah-buahan tidak selalu dikonsumsi dalam bentuk segar. Tetapi sebagian besar diolah menjadi berbagai bentuk dan jenis makanan. Pengolahan ini bertujuan selain untuk memperpanjang masa simpan, juga untuk meningkatkan aneka ragam produk. Buahbuahan umumnya diolah menjadi olahan seperti jam, jelly, selai, puree, sari buah, buah kaleng, manisan kering atau basah. Salah satu jenis produk buah-buahan yang kering selain manisan buah-buahan adalah Fruit leather. Fruit leather adalah jenis makanan dari daging buah yang telah dihancurkan dan dikeringkan. Pengeringan bisa dilakukan dengan penjemuran atau bisa juga dengan pemanasan yang memiliki suhu panas $50-60^{\circ} \mathrm{C}$. Fruit leather memiliki daya simpan sampai 12 bulan, bila disimpan pada kondisi penyimpanan yang sesuai. Di Indonesia, Fruit leather masih belum diproduksi secara komersial. Bahan baku Fruit leather dapat berasal dari berbagai jenis buah-buahan tropis ataupun subtropis dengan kandungan serat yang cukup tiinggi seperti pisang, pepaya, mangga, nenas, jambu biji, apel, nangka, peach dan sebagainya.

Mangga merupakan salah satu jenis buahbuahan yang produksinya cukup tinggi dan banyak disukai oleh masyarakat. Selain cita rasa, aroma yang enak serta penampakan yang menarik, juga banyak mengandung vitamin dan mineral yang sangat bermanfaat bagi pertumbuhan dan kesehatan badan (Anonim, 2011). Komponen utama dari buah mangga adalah air, karbohidrat (dalam bentuk gula) dan vitamin. Komponen lain terdiri dari berbagai macam asam, protein, mineral, zat warna, tanin dan zat-zat volatile (ester) yang memberikan bau harum (khas). Vitamin $\mathrm{C}$ pada buah mangga berkisar antara 18-80 mg / $100 \mathrm{~g}$ tergantung varietas (Anonim, 2012).

Tanaman rosella memiliki lebih dari 300 spesies yang tersebar pada daerah tropis dan non-tropis. Biasanya, digunakan sebagai tanaman hias dan beberapa diantaranya dipercaya memiliki khasiat medis, salah satu diantaraya adalah rosella merah atau rosella (Ullych, 2009). Kandungan senyawa metabolis sekunder yang paling dominan pada rosella merah adalah adanya senyawa antosianin yang membentuk flavonoid yang berperan sebagai antioksidan. Flavonoid rosella terdiri dari flavonos dan figmen antosianin. Antosianin berfungsi sebagai antioksidan yang diyakini dapat menyembuhkan penyakit degeneratif. Selain itu kelopak rosella juga mengandung protein, serat kasar, sodium, vitamin $\mathrm{C}$ dan vitamin $A$. Kandungan vitamin $C$ dan vitamin $A$ rosella cukup tinggi jika dibandingkan dengan buah-buahan seperti jeruk, apel, pepaya dan jambu biji yang berfungsi untuk meningkatkan daya tahan tubuh manusia terhadap serangan penyakit. Kelopak bunga rosella juga diketahui dapat membantu melancarkan peredaran darah 
dengan mengurangi derajat kekentalan darah. Hal ini terjadi karena adanya asam organik, poly-sakarida dan flavonoid yang terkandung didalam ekstrak kelopak bunga rosella sebagai efek farmakologi.

Kelopak bunga rosella memiliki rasa asam yang unik karena dapat memberikan perasaan yang menyegarkan saat dikonsumsi. Rasa asam ini disebabkan karena adanya dua konponen senyawa asam yang dominan yaitu asam askorbat (vitamin C), asam sitrat dan asam malat. Kandungan asam askorbat (vitamin C) dan betakarotin yang tinggi merupakan sumber antioksidan alami yang efektif dalam menangkal berbagai radikal bebas penyebab kanker dan berbagai penyakit lainnya. Pada biji rosella juga terdapat asam lemak yang diantaraya adalah asam palmitat, asam oleat dan asam linoleat. Kelopak rosella juga terdapat 18 asam anino yang diperlukan oleh tubuh, termasuk arginin dan lisin yang berperan dalam proses peremajaan sel tubuh. Sebagai tanaman obat, rosella mempunyai manfaat untuk mengatasi berbagai masalah penyakit dan maslah kesehatan. Manfaat dari rosella merah antara lain dapat menurunkan asam urat, menurunkan kadar kolesterol dalam tubuh, menghancurkan lemak, melangsingkan tubuh, mengurangi kecanduan merokok, mencegah stroke dan hipertensi, memperbaiki pencernaan, menghilangkan wasir, menurunkan kadar gula dalam darah, mencegah kanker, tumor, kista dan sejenisnya. Diantara banyak khasiatnya, rosella diunggulkan sebagai herba antikanker, antihipertensi, dan antideabetes (Anonim, 2010). Bagian tanaman rosella merah yang paling banyak dimanfaatkan untuk produk pangan maupun non-pangan adalah kelopak bunga rosella. Contoh hasil produk pangan dari hasil olahan rosella antara lain teh, salat, jelly, selai, dodol, sirup, jus, kopi dan lain-lain. Serbuk kopi rosella berasal dari bagian biji yang proses pembuatannya sama dengan proses pembuatan kopi pada umumnya. Kadar kafein pada kopi biji rosella bubuk adalah 0,87\%. Kadar kafein tersebut lebih rendah jika dibanding dengan kadar kafein pada kopi jenis kopi arabika dan robusta yang kadarnya mencapai lebih dari $1 \%$ (Mardiah dkk, 2009).

Fruit leather adalah jenis makanan yang berasal dari daging buah yang telah dihancurkan dan dikeringkan. Produk ini bukan berasal dari kulit buah. Namun dari daging buah-buahan, umumnya buah-buahan tropis, yang dibuburkan lalu diolah hingga membentuk lembaran tipis dengan tekstur yang plastis, rasanya manis tetapi masih memiliki citarasa khas buah yang digunakan. Fruit leather mempunyai keuntungan tertentu yaitu daya simpan yang cukup tinggi, mudah diproduksi, dan nutrisi yang terkandung didalamnya tidak banyak berubah. Selain itu, biaya penanganan, pengangkutan, dan penyimpanan relatif mudah karena lebih murah dan sederhana (Anonim, 2011). Fruit lether merupakan produk makanan berbentuk lembaran tipis dengan ketebalan 2-3 mm, kadar air 10-25\%, yang mempunyai konsistensi dan cita rasa khas suatu jenis buah. Buah-buahan yang baik digunakan sebagai bahan baku pembuatan fruit lether adalah yang mempunyai kandungan serat yang tingi. Fruit leather adalah sejenis manisan yang dikeringkan yang dapat dijadikan sebagai bentuk olahan komersial dalam skala industri dengan cara yang sangat mudah, yaitu menghancurkan buah menjadi puree dan mengeringkannya (Raab \& Oehler, 2000). Fruit leather dapat dibuat dari satu jenis buahbuahan atau campuran beberapa jenis buahbuahan. Kadar air fruit leather berdasarkan standar Nasional Indonesia yaitu maksimal $25 \%$, nilai AW kurang dari 0,7, tekstur plastis, kenampakan seperti kulit, terlihat mengkilap, dapat dikonsumsi secarra langsung serta mempunyai warna, aroma, dan cita rasa khas suatu buah sebagai bahan baku (Nurlaely, 2002).

\section{B. METODOLOGI \\ Bahan dan Alat}

Bahan penelitian yang digunakan adalah daging buah mangga udang, harum manis dan kueni, kelopak bunga rosella (merah), Gula pasir, Jeruk nipis, Gum arab, Aquades, Larutan buffer pH7, dan $\mathrm{NaOH} \mathrm{0,1} \mathrm{N.} \mathrm{Peralatan} \mathrm{yang}$ digunakan Blender, Timbangan analitik, Loyang, Baskom, Pisau, Sendok, Pengaduk, Labu takar, Erlenmeyer, $\mathrm{pH}$ meter dan Oven.

\section{Pelaksanaan Penelitian}

Pertama kita lakukan pemilihan buah mangga dan rosella yang baik dan segar, kemudian dicuci hingga bersih dari kotoran. Buah mangga diambil daging buahnya sedang rosella diambil kelopaknya. Kemudian kedua bahan tadi ditimbang sesuai dengan proporsinya lalu dihancurkan menggunakan blender, agar didapat bahan yang lebih halus. 
Kemudian dilakukan penambahan gula, gum arab dan juga jeruk nipis dengan persentase sesuai dengan perlakuan yang telah ditentukan. Perlakuan berikutnya adalah melakukan pemanasan dengan menggunakan oven dengan pengaturan suhu $70-80^{\circ} \mathrm{C}$ dengan waktu selama 5-10 menit. Setelah dilakukan pemanasan selama 5-10 menit, bahan sudah siap untuk dilakukan pencetakan. Dalam penelitian ini alat untuk pencetakan menggunakan loyang dengan ketebalan $3 \mathrm{~mm}$. Langkah selanjutnya yaitu, setelah bahan dingin kemudian dapat dilakukan pengeringan pada sampel dengan suhu $60^{\circ} \mathrm{C}$ selama 24 jam dengan menggunakan oven pengering. Setelah dilakukan pengeringan selama 24 jam dan didapat kadar air pada bahan sebesar $10 \%$ kemudian dapan dilakukan pemotongan bahan dengan ketebalan sesuai standart yang benar dalam pembuatan Fruit leather. Setelah dilakukan pemotongan didapatlah hasil Fruit leather.

\section{Rancangan Penelitian}

Pelaksanaan Penelitian menggunakan Rancangan Acak Lengkap (RAL) Faktorial, dengan dua faktor utama yaitu :

Faktor I: Varietas buah mangga (M) yang terdiri dari 3 taraf; M: Mangga udang, M2: Mangga harum manis, M3: Kueni.

Faktor II: Penambahan rosella (\%) dari daging buah mangga, yang terdiri dari 4 taraf; R1: $40 \%$, R2: $60 \%$, R3: 80\%, R4: 100\%. Penelitian dilaksanakan dengan 3 ulangan.

\section{HASIL DAN PEMBAHASAN}

\section{Pengaruh Jumlah Pasta Labu Kuning Terhadap Kadar Air Mi Basah}

Dari hasil penelitian dan uji statistik, secara umum menunjukkan bahwa varietas buah mangga berpengaruh terhadap parameter yang diamati. Data rata-rata hasil pengamatan pengaruh varietas buah mangga dan penambahan rosella terhadap parameter yang diamati disajikan pada Tabel 1 dan Tabel 2.

Tabel 1 Pengaruh Varietas Buah Mangga Terhadap Parameter Yang Diamati

\begin{tabular}{|c|c|c|c|c|c|c|}
\hline \multirow{2}{*}{$\begin{array}{l}\text { Varietas } \\
\text { Buah } \\
\text { Mangga } \\
\text { (J) }\end{array}$} & \multirow{2}{*}{$\begin{array}{c}\text { Kadar } \\
\text { Vitamin } \\
\text { C }\end{array}$} & \multirow{2}{*}{$\begin{array}{c}\text { Kadar } \\
\text { Air }\end{array}$} & \multicolumn{4}{|c|}{ Organoleptik } \\
\hline & & & Warna & Pace & Arom & Tekstur \\
\hline M1 & $9,14 \mathrm{a}$ & & & & b & \\
\hline M2 & 8,68 & $16,70 \mathrm{a}$ & & $3,08 \mathrm{~b}$ & $3,08 \mathrm{a}$ & $2,84 \mathrm{~b}$ \\
\hline M3 & $8,96 \mathrm{c}$ & $16,40 \mathrm{a}$ & $3,45 \mathrm{a}$ & $3,18 \mathrm{a}$ & $3,24 b$ & $2,74 \mathrm{a}$ \\
\hline
\end{tabular}

Tabel 2. Pengaruh Jumlah Penambahan Rosella Terhadap Parameter Diamati

\begin{tabular}{|c|c|c|c|c|}
\hline \multirow{2}{*}{$\begin{array}{l}\text { Varietas } \\
\text { Buah } \\
\text { Mangga } \\
\text { (J) }\end{array}$} & \multirow{2}{*}{$\begin{array}{cc}\text { Kadar } & \\
\text { Vitamin } & \text { Kadar } \\
\text { C } & \text { Air }\end{array}$} & \multicolumn{3}{|c|}{ Organoleptik } \\
\hline & & Warna & Rasa & Aroma Tekstu \\
\hline $\mathrm{R} 1=40 \%$ & $6,18 \mathrm{a} \quad 17,44 \mathrm{a}$ & $3,33 a$ & $3,18 \mathrm{~b}$ & $3,31 \mathrm{~b} \quad 2,84 \mathrm{~b}$ \\
\hline $\mathrm{R} 2=60 \%$ & 8,12 b $16,67 a$ & $3,40 \mathrm{ab}$ & $3,11 a b$ & $3,23 \mathrm{~b} \quad 2,79 \mathrm{~b}$ \\
\hline $\mathrm{R} 3=80 \%$ & 9,70 c $16,02 \mathrm{a}$ & $3,47 \mathrm{bc}$ & $3,04 \mathrm{a}$ & $3,14 a b 2,72 a b$ \\
\hline $\mathrm{R} 4=100 \%$ & $11,71 \mathrm{~d} 15,56$ & $3,52 c$ & $3,02 \mathrm{a}$ & 3,02 a $2,66 a$ \\
\hline
\end{tabular}

Dari Tabel 1 dapat dilihat bahwa varitas mangga mempengaruhi rasa, aroma, tekstur dan kadar vitamin C. Pada Tabel 2. Dapat dilihat bahwa penambahan rosella cenderung menyebabkan penurunan nilai organolepik rasa, aroma, tekstur sebaliknya warna dan kadar vitamin $\mathrm{C}$ meningkat.

\section{Pengaruh Varitas Mangga Dan Penambahan Rosella Terhadap Nilai Organoleptik}

Varitas mangga memberi pengaruh yang berbeda nyata $(\mathrm{P}<0,05)$ terhadap nilai organoleptik rasa, aroma dan tekstur, sebaliknya tidak berbeda nyata $(\mathrm{P}>0,05)$ terhadap organoleptik warna. Organoletik rasa dan aroma tertinggi diperoleh pada buah mangga kueni. Hal ini terkait dengan aroma dan rasa kueni yang khas dan kuat sehingga mendominasi rasa dan aroma fruit leather yang dihasilkan. Sementara rasa dan aroma mangga udang dan mangga harum manis tidak sekuat aroma dan rasa kueni. Sebaliknya Tekstur terbaik diperoleh pada varitas mangga harum manis, tekstur lembut yang didapat berkaitan dengan daging buah mangga harum manis yang mengandung lebih sedikit serat dibanding dengan mangga udang dan kueni. Serat pada buah ternyata mengakibatkan tektur menjadi lebih kasar. Ternyata hal ini kurang disukai panelis. Selanjutnya Varitas mangga memberi pengaruh tidak berbeda nyata $(\mathrm{P}>0,05)$ terhadap organoleptik warna. Hal ini tentunya berhubungan langsung dengan warna daging buah dari ketiga varitas yang digunakan relatif sama (kuning) sehingga menghasilan warna fruit leather yang tidak berbeda. 


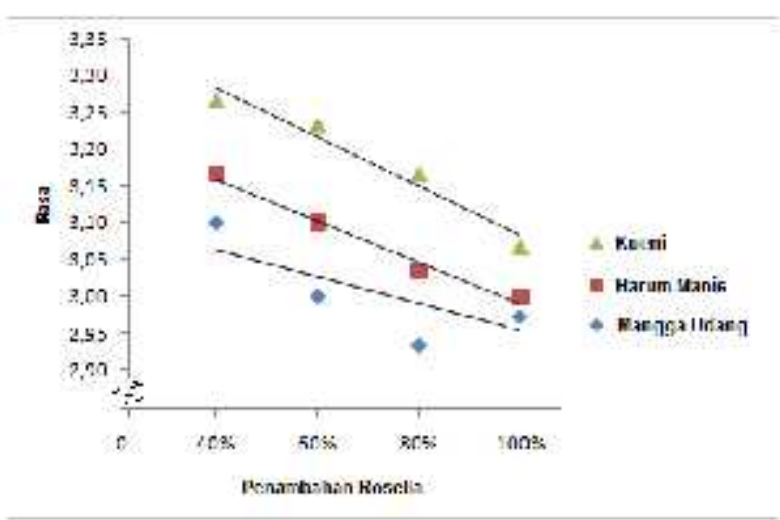

Gambar 1 Pengaruh Penambahan Kelopak Bunga Rosella Terhadap Organoletik Rasa

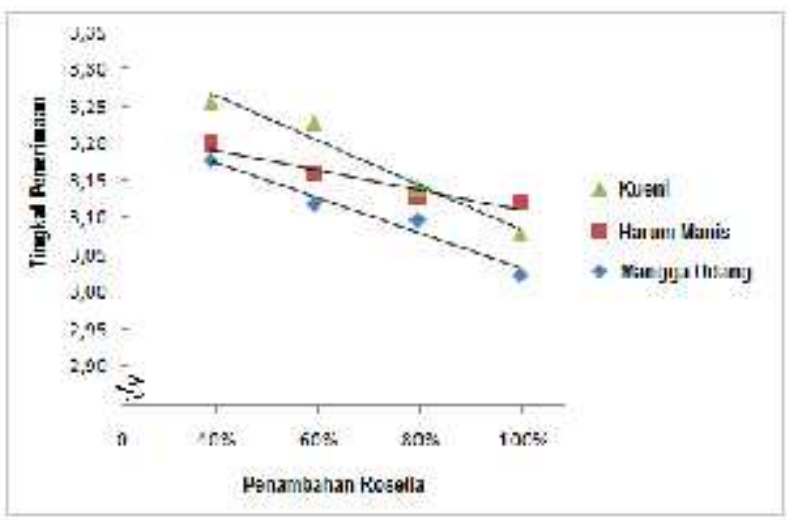

Gambar 2 Pengaruh Penambahan Kelopak Bunga Rosella Terhadap Tingkat menerimaan Umum panelis

Penambahan kelopak bunga rosella memberi pengaruh yang berbeda nyata $(\mathrm{P}<0,05)$ terhadap nilai organoleptik rasa, aroma, warna dan tekstur. Warna merah dari kelopak bunga rosella mendominasi warna fruit leather yang dihasilkan. Semakin banyak penambahan rosella semakin merah fruit leather yang dihasilkan, warna ini ternyata sangat disukai panelis. Sebaliknya semakin banyak jumlah penambahan rosella ternyata mengakibatkan penurunan nilai organoleptik rasa, aroma dan tekstur. Hal ini disebabkan rasa dan aroma khas buah mangga tertutup oleh aroma dan rasa rosella, sehingga menhasilkan kombinasi rasa dan aroma yang kurang disukai panelis. Demikian pula halnya serat kelopak bunga rosella menyebabkan penurunan nilai organoleptik tekstur.

\section{Pengaruh Varitas Manga dan Rosella Terhadap Kadar Air dan Vitamin C}

Varitas mangga dan penambahan Rosella memberi pengaruh yang berbeda tidak nyata $(P>0,05)$ terhadap kadar air fruit leather tetapi memberi pengaruh yang berbeda nyata terhadap kadar vitamin C. Sumber vitamin C tentunya dai bahan baku yang digunakan. Mangga uadang mengasilkan kadar vitamin C tertnggi diikukti oleh mangga kueni dan harum manis. Secara keseluruhan ketiganya masih memiliki kandungan vitamin $C$ yang cukup baik. Sedangkan penambahan rosella akan meningkatkan kandungan vitamin $\mathrm{C}$ fruit elather yang dihasilkan, hal ini terkait dengan kandungan vitamin $\mathrm{C}$ pada kelopak bunga rosella yang relatif lebih tinggi.

\section{KESIMPULAN}

1. Fruits Leather terbaik diperoleh pada perlakuan M3 yaitu mangga kueni dengan penambahan kelopak bunga rosella sebanyak $40 \%$.

2. Semakin banyak penambahan kelopak bunga rosella meningkatkan organoleptik warna tetapi akan mengakibatkan penurunan nilai organoleptik rasa, aroma dan tekstur.

\section{SARAN}

1. Untuk membuat fruits leather dari buah mangga sebaiknya digunakan buah mangga kuini dan dapat juga dikombinasikan dengan penambahan daging kolopak bunga rosella sebanyak $40 \%$.

2. Dapat juga dilakukan penelitian lebih lanjut tentang perbandingan jumlah buah mangga kuini dengan kelopak bunga rosella untuk membuat fruits leather

\section{DAFTAR PUSTAKA}

Anonim, 2010. Manfaat Rosella dan Semua Tentang Rosella. (Serial Online) http://direktori.kreatif.web.id/goto/http //mbahgendeng.com/kesehatan/manfaat -rosella-dan-semua-tentang -rosella.html. akses tanggal 1 September 2016.

Anonim, 2011. Klasifikasi Buah Mangga. (Serial Online) http://www.

Plantarum.com/indekx.php?plant=812. Pada Tanggal 8 Desember 2016, Medan.

Anonim, 2012, Mangga. (Serial Online) http://id.wikipedia.org/wiki/mangga. Pada tanggal 8 Desember 2016, Medan.

Alinkolis, J.J., 1989. Candy Technology. The AVI Publishing Co. Westport-Connecticut. 
Buckle, K.A, R.A. Edwards, G.H. Fleet dan wootton, 1985. Food Science. Penerjemah hari purnomo dan adiono dalam ilmu pangan. Universitas Indonesia press, Jakarta.

Erianto, 2009. Budidaya Rosella. (Serial Online) http://makalahbudidayrosela<<onesubenol.wordpress.com. Pada tanggal 8 Desember 2016, Medan.

Gaonkar, A.G., 1995. Inggredient Interactions Effects on Food Quality. Marcell Dekker, Inc., New York.

Imeson, A., 1999. Thickening and Gelling Agent for Food. Aspen Publisher Inc, New York.

Mardiah, Arifah, R., Reki, W. dan Sawarni, H., 2009. Budidaya dan Pengolahan Rosella Si Merah Segudang Manfaat. Agromedia Pustaka, Jakarta.

Nurlaely, E., 2002. Pemanfaatan Buah Jambu Mete Untuk Pembuatan Leather. Kajian Dari Proporsi Buah Pencampur. [Skripsi]. Jurusan Teknologi Hasil Pertanian. Unversitas Brawaijaya Malang.

Raab, C. and Oehler, N., 2000. Making Dried Fruit leather. Extention Foods and Nutrition Specialist. Origon State University. 